\title{
Phytoremediation of urban soils contaminated with trace metals using Noccaea caerulescens: comparing non-metallicolous populations to the metallicolous 'Ganges' in field trials
}

\author{
Arnaud Jacobs $^{1}$ (D) $\cdot$ Thomas Drouet $^{1} \cdot$ Thibault Sterckeman $^{2} \cdot$ Nausicaa Noret ${ }^{1}$
}

Received: 12 August 2016/Accepted: 23 January 2017 /Published online: 31 January 2017

(C) Springer-Verlag Berlin Heidelberg 2017

\begin{abstract}
Urban soil contamination with trace metals is a major obstacle to the development of urban agriculture as crops grown in urban gardens are prone to accumulate trace metals up to toxic levels for human consumption. Phytoextraction is considered as a potentially cost-effective alternative to conventional methods such as excavation. Field trials of phytoextraction with Noccaea caerulescens were conducted on urban soils contaminated with $\mathrm{Cd}, \mathrm{Cu}, \mathrm{Pb}$, and $\mathrm{Zn}$ (respectively around 2, 150-200, 400-500, and 400-700 $\mu \mathrm{g} \mathrm{g}^{-1}$ of dry soil). Metallicolous (Ganges population) and non-metallicolous (NMET) populations were compared for biomass production and trace metal uptake. Moreover, we tested the effect of compost and fertilizer addition. Maximal biomass of $5 \mathrm{t} \mathrm{ha}^{-1}$ was obtained with NMET populations on some plots. Compared to Ganges - the high Cd-accumulating ecotype from South of France often used in phytoextraction trials - NMET populations have an advantage for biomass production and for $\mathrm{Zn}$ accumulation, with an average $\mathrm{Zn}$ uptake of 2.5 times higher. The addition of compost seems detrimental due to metal immobilization in the soil with little or no effect on plant growth.
\end{abstract}

Responsible editor: Elena Maestri

Electronic supplementary material The online version of this article (doi:10.1007/s11356-017-8504-9) contains supplementary material, which is available to authorized users.

Arnaud Jacobs

arjacobs@ulb.ac.be

1 Laboratoire d'Écologie Végétale et Biogéochimie, CP 244, Faculté des Sciences, Université Libre de Bruxelles, 50 av. F. D. Roosevelt, B-1050 Brussels, Belgium

2 Laboratoire Sols et Environnement, INRA-Université de Lorraine, 2 avenue de la Forêt de Haye, TSA 40602,

F-54518 Vandoeuvre-lès-Nancy Cédex, France
In addition to differences between populations, variations of growth and metal accumulation were mostly explained by soil $\mathrm{Cd}$ and $\mathrm{Zn}$ concentrations and texture. Our field trials confirm the potential of using $N$. caerulescens for both $\mathrm{Cd}$ and $\mathrm{Zn}$ remediation of moderately contaminated soils - with uptake values of up to $200 \mathrm{~g} \mathrm{Cd} \mathrm{ha}^{-1}$ and $47 \mathrm{~kg} \mathrm{Zn} \mathrm{ha}^{-1}$ —and show the interest of selecting the adequate population according to the targeted metal.

Keywords Cadmium · Hyperaccumulation · Phytoextraction · Soil remediation - Thlaspi caerulescens . Zinc

\section{Introduction}

One of the main threats on urban soils is the contamination with trace metals like lead $(\mathrm{Pb})$, cadmium $(\mathrm{Cd})$, copper $(\mathrm{Cu})$, nickel $(\mathrm{Ni})$, and zinc $(\mathrm{Zn})$ or organic contaminants such as polycyclic aromatic hydrocarbons. In urban environments, the anthropogenic sources of trace metals include primarily atmospheric inputs from industrial activities, waste incineration, and car use as well as solid inputs such as construction wastes (Alloway 2012; Wong et al. 2006). In contrast with agricultural soils, urban soils are characterized by the spatial heterogeneity of contamination (Alloway 2012; Meuser 2010), which complicates remediation strategies. Urban soil contamination by toxic trace metals is detrimental for soil quality but is also harmful for human health resulting from accidental soil ingestion and consumption of crops grown on these soils, generally more exposed to trace metals than when grown in rural areas (Finster et al. 2004; Hough et al. 2004; Säumel et al. 2012; Wang et al. 2005). Conventional soil remediation practices such as excavation are often considered 
too difficult and too costly to be implemented on enclosed urban surfaces that could be converted for agricultural use.

Phytoextraction with hyperaccumulating plants has been suggested to be a promising technique to remediate soils contaminated with trace metals (Hammer and Keller 2003; Koopmans et al. 2008; Maxted et al. 2007; McGrath et al. 2006; Robinson et al. 1998; Schwartz et al. 2003; Zhao et al. 2003). Hyperaccumulating plants accumulate metals in shoots at concentrations above defined thresholds when grown in their natural habitats, i.e., $100 \mu \mathrm{g} \mathrm{g}^{-1}$ for $\mathrm{Cd}, 1000 \mu \mathrm{g} \mathrm{g}$ for $\mathrm{Ni}$, or $3000 \mu \mathrm{g} \mathrm{g}^{-1}$ for $\mathrm{Zn}$, on a dry weight basis (Krämer 2010; van der Ent et al. 2013).

The small size and short life cycle of hyperaccumulating plants can be viewed as an advantage for the remediation of small and enclosed surfaces such as urban plots. The technique could be worth considering only with moderate total and highly available trace metal concentrations (Hammer and Keller 2003; Zhao et al. 2003), i.e., less than $10^{3}$ and $10^{2} \mathrm{mg} \mathrm{kg}^{-1}$ of soil total $\mathrm{Zn}$ and $\mathrm{Cd}$, respectively (Zhao et al. 2003). Therefore, the concept of bioavailable contaminant stripping (BCS) - which aims at removing only the bioavailable metal pools - is thought to be a more realistic alternative (Hamon and McLaughlin 1999).

$N$. caerulescens (Brassicaceae, formerly Thlaspi caerulescens) is one of the most promising candidate species for $\mathrm{Cd}$ and $\mathrm{Zn}$ phytoextraction (Koopmans et al. 2008; Maxted et al. 2007; McGrath et al. 2006; Zhao et al. 2003). Three ecotypes of $N$. caerulescens have been described: metallicolous plants grow in soils enriched in $\mathrm{Cd}-\mathrm{Zn}-\mathrm{Pb}$ (calamine, CAL) and in serpentine sites (mostly enriched in $\mathrm{Ni}$ ), whereas non-metallicolous (NMET) grow in uncontaminated soils (Escarré et al. 2000; Meerts and van Isacker 1997; Molitor et al. 2005; Reeves et al. 2001).

CAL and NMET ecotypes have different metal-related traits. When grown in the same substrate, NMET accumulate more Zn (about twice) and Ni than CAL (Escarré et al. 2000; Meerts and van Isacker 1997), and NMET can reach $20,000 \mu \mathrm{g} \mathrm{g}^{-1}$ of $\mathrm{Zn}$ on moderately contaminated substrates (Dechamps et al. 2007). On the other hand, high Cd CAL populations from South of France (such as Saint-Félix or Ganges) have been identified for their great potential of $\mathrm{Cd}$ phytoextraction, as they can accumulate up to $1000 \mu \mathrm{g} \mathrm{g}^{-1}$ (Hammer and Keller 2003; Lombi et al. 2001; Robinson et al. 1998; Zhao et al. 2003), compared to $300 \mu \mathrm{g} \mathrm{g}^{-1}$ for NMET (Dechamps et al. 2005). Furthermore, life history traits of $N$. caerulescens differ according to the geographic origin and among ecotypes: NMET populations from Luxemburg are mostly short-lived monocarpic perennials while CAL from South of France are in general winter annuals (Dechamps et al. 2011; Jiménez-Ambriz et al. 2007). Lastly, CAL populations are less adapted to herbivore attacks than NMET as they exhibit lower levels of chemical defenses (e.g., lower glucosinolate concentrations) (Noret et al. 2005, 2007).
The potential efficiency of phytoextraction with $N$. caerulescens has first been tested in pot trials using soils spiked with metals or from polluted field sites (e.g., Robinson et al. 1998; Escarré et al. 2000; Keller and Hammer 2004). These studies concluded that phytoextraction offers a great potential for $\mathrm{Cd}$ and $\mathrm{Zn}$ remediation achievable in a few crops for moderate soil concentrations. Despite the need of field experiments on a range of soil conditions to assess the actual phytoextraction efficiency, the number of field trials reported in the literature is surprisingly still very scarce (Hammer and Keller 2003; Maxted et al. 2007; McGrath et al. 2006; Schwartz et al. 2003; Simmons et al. 2015; Tlustoš et al. 2016), in comparison to pot experiments (see 14 references in Li et al. 2012). So far, the limits of the method and the biggest lack of knowledge that still need to be field tested concern the adequate agricultural practices, e.g., fertilization, weed and pest control, irrigation and resistance to hot weather, and optimal length of growth (Koopmans et al. 2008; Li et al. 2012; Maxted et al. 2007; McGrath et al. 2006; Vangronsveld et al. 2009).

Adequate fertilization is expected to be the most important practice for increasing biomass production. Concerning the use of synthetic fertilizers, previous pot studies showed that nitrogen fertilization enhances $N$. caerulescens biomass production $(+30 \%)$ (Sirguey et al. 2006), while its effects on phytoextraction efficiency can either be neutral (Sirguey et al. 2006) or positive with a stronger effect with $\mathrm{NO}_{3}{ }^{-}$compared to $\mathrm{NH}_{4}^{+}$(Monsant et al. 2008; Schwartz et al. 2003). In the case of Ni phytomining, Álvarez-López et al. (2016) showed that compost addition enhances biomass production and extraction by Ni hyperaccumulators, despite lowering metal bioavailability. The effect of compost addition has however never been tested with $N$. caerulescens while organic amendments such as compost have the advantage of positively influencing soil biological, chemical and physical characteristics (Bulluck et al. 2002), and of being produced in urban environments.

In summary, strategies to improve phytoextraction efficiency can be classified in two categories: (i) the improvement of the agronomic practices and (ii) the selection of outstanding populations or individuals based on desired agronomic and phytoextraction characteristics ( $\mathrm{Li}$ et al. 2012; Schwartz et al. 2006; Vangronsveld et al. 2009).

The present study tested the phytoextraction technique with both metallicolous and non-metallicolous populations of $N$. caerulescens in field conditions in the context of urban soil remediation for agricultural use. NMET from Luxemburg have never been tested as potential candidates for phytoextraction despite their outstanding metal accumulation capacities (Meerts and Van Isacker 1997), most field studies using the high Cd CAL ecotype (Maxted et al. 2007; McGrath et al. 2006). Field trials are of crucial importance to assess which soil parameters influence most biomass production and phytoextraction efficiency, and evaluate the potential of 
the method and its limits. Therefore, the objectives of the present study were to: (i) compare MET and NMET populations in phytoextraction field trials, (ii) test the effect of compost addition on biomass production and phytoextraction efficiency, and (iii) test the potential of phytoextraction for remediation of urban soils.

\section{Materials and methods}

\section{Site description}

Field trials were conducted in two urban wastelands located in Brussels, Belgium. The first one, Gare Royale (GR) (50 52" $07^{\prime \prime} \mathrm{N}, 4^{\circ} 21^{\prime \prime} 39^{\prime \prime} \mathrm{E}$ ), is located along a railway on an embankment slope created at the end of the nineteenth century. The second one, Masui (MAS) (50 52" 31" N, 4 21" 40" E), lies on the old bed of the river Senne, which has been diverted and filled in the middle of the twentieth century. Both sites are contaminated with trace metals and PAH (polycyclic aromatic hydrocarbons) and consist of embankment material at $1 \mathrm{~m}$ depth (ballast, slags, and bricks). On average, five PAH out of 16 are slightly above regional thresholds but the total PAH content is globally low (sum of $16 \mathrm{PAH}, 22 \pm 5 \mathrm{mg} \mathrm{kg}^{-1}$ at $\mathrm{GR} ; 40 \pm 60 \mathrm{mg} \mathrm{kg}^{-1}$ at MAS) (Geosan 2013). Due to the high cost of remediation, the foreseen conversion of the sites by the city is on hold. Topsoils of both sites are characterized by a neutral $\mathrm{pH}(\mathrm{GR}, 7.2)$ or alkaline (MAS, 8.2), a coarse texture (sandy loam) and a very high loss on ignition for GR (19.7\% and around $10 \%$ organic matter when coal is subtracted; MAS, $5.7 \%)$. Average nitrate $\left(\mathrm{NO}_{3}{ }^{-}\right)$and ammonium $\left(\mathrm{NH}_{4}{ }^{+}\right)$levels of the top soil are twice higher at GR (44 and $10 \mathrm{mg} \mathrm{kg}^{-1}$, respectively) than at MAS (23 and $\left.5 \mathrm{mg} \mathrm{kg}^{-1}\right)$. Vegetation on both sites is mostly composed of pioneer and invasive species which thrive on frequently disturbed wastelands (e.g., Urtica dioica, Rubus idaeus, Buddleja davidii).

Climatic conditions during growth season (MayNovember) in 2014 (recorded in Uccle, Royal Meteorological Institute) were the following: mean monthly temperature of $14.9^{\circ} \mathrm{C}$ (ranging from $8.8^{\circ} \mathrm{C}$ in November to $19.3^{\circ} \mathrm{C}$ in July), mean monthly rainfall of $73.7 \mathrm{~mm}$ (ranging from $15.1 \mathrm{~mm}$ in September to $136 \mathrm{~mm}$ in August), and total rainfall during the growth period of $516 \mathrm{~mm}$.

\section{Experimental design and plant cultivation}

N. caerulescens seeds came from three populations: two NMET from the Grand Duchy of Luxemburg, Wilwerwiltz. and Goebelsmühle (hereafter WIL and GOE) (Molitor et al. 2005), and one metallicolous Ganges (GAN, or "Avinières") from St-Laurent-le-Minier, France (Escarré et al. 2000). Seedlings of $N$. caerulescens were grown in greenhouse for 2.5 months before transplanting in the field.
In each site, four blocks $(3.6 \times 1 \mathrm{~m})$ were set up and split into three plots $(1 \times 1 \mathrm{~m})$ corresponding to three treatments each separated by $30 \mathrm{~cm}$ (compost addition, fertilization, control). Each block was excavated to $20 \mathrm{~cm}$ depth and the topsoil was thoroughly homogenized before being replaced. On the appropriate plots, fertilizer and amendment were applied 2 weeks before transplantation. Green waste compost (containing $1.4 \mathrm{~g} \mathrm{P}_{2} \mathrm{O}_{5}, 8.8 \mathrm{~g} \mathrm{~K}_{2} \mathrm{O}, 1.3 \mathrm{~g} \mathrm{MgO}, \mathrm{Cd} 0.35 \mathrm{mg}, \mathrm{Cu}$ $9.2 \mathrm{mg}, \mathrm{Pb} 23 \mathrm{mg}, \mathrm{Zn} 70 \mathrm{mg} \mathrm{kg}^{-1}$, as exchangeable ions) was spread at the rate of $20 \mathrm{~L} \mathrm{~m}^{-2}$. Fertilizer made of chicken manure and meat-and-bone meal (500 g organic matter, $60 \mathrm{~g}$ $\mathrm{N}, 30 \mathrm{~g} \mathrm{P}_{2} \mathrm{O}_{5}$, and $50 \mathrm{~g} \mathrm{~K}_{2} \mathrm{O} \mathrm{kg}^{-1}$ ) was added as a $60 \mathrm{~g} \mathrm{~m}^{-2}$ split in one initial application followed by one each month. Quantities applied were chosen based on fertility recommendations for small Brassicaceae and on the very poor quality of the wasteland soils.

Each plot was then divided into four subplots $(0.5 \times 0.5 \mathrm{~m})$ to compare different populations. In three subplots, twenty-five seedlings of $N$. caerulescens (four leaves stage) per population were transplanted in May 2014, every $10 \mathrm{~cm}$ (density $100 \mathrm{~m}^{-2}$ ). The last subplot was left unplanted for control. Plants were watered ( $5 \mathrm{~L} \mathrm{~m}^{-2}$ every other week if it had not rained) and plots were weeded twice a month. Flower stalks were systematically cut off to favor vegetative growth. Aerial parts of $N$. caerulescens were harvested in November 2014 after 6.5 months of growth by cutting the plants at the root collar. Four plants were selected in each subplot for elemental composition analysis based on their proximity to the points of soil sampling (see after). The rest of the plants was collected, rinsed once with tap water, and dried. Aboveground biomasses of $65^{\circ} \mathrm{C}$ dried plants were determined for every subplot, and the number of individuals was counted to determine the survival rate. Mean individual biomass was calculated by dividing total biomass by the number of surviving individuals at harvest.

\section{Soil analysis}

Before and after cultivation, soil samples were collected with a 2-cm-diameter auger down to $20 \mathrm{~cm}$ depth at four points in each subplot; the four samples were bulked as one composite sample per subplot. Soil treatments were applied 2 weeks before the first soil sampling.

All measurements - except those specifically mentionedwere carried out following standard protocols of soil analysis (Pansu and Gautheyrou 2006). Soil samples were air-dried and sieved at $2 \mathrm{~mm}$. Soil $\mathrm{pH}-\mathrm{H}_{2} \mathrm{O}$ was measured using glass electrodes in a 1:5 soil/water suspension. Soil/water content (moisture) was measured after cultivation as the loss on drying at $105^{\circ} \mathrm{C}$. Exchangeable cations $\left(\mathrm{Ca}^{2+}, \mathrm{Mg}^{2+}, \mathrm{K}^{+}, \mathrm{Fe}^{3+}, \mathrm{Zn}^{2+}\right.$, $\left.\mathrm{Cd}^{2+}, \mathrm{Cu}^{2+}, \mathrm{Ni}^{2+}, \mathrm{Pb}^{2+}\right)$ were extracted with ammonium acetate $(0.5 \mathrm{M})$ and EDTA $(0.02 \mathrm{M})$ at $\mathrm{pH} 7$ (Cottenie et al. 1979) 
and their concentrations were measured with inductively coupled plasma emission spectrometer (ICP-OES) (Varian Vista-MPX). Organic matter (OM) content was measured by loss on ignition at $500{ }^{\circ} \mathrm{C}$. The cation exchange capacity (CEC, $\mathrm{cmol}_{\mathrm{c}} \mathrm{kg}^{-1}$ ) was measured on a soil extract with cobaltihexamine trichloride according to the ISO norm 23470: 2007. Soil texture (percentage of clay, silt, and sand) was determined using wet sieving and the pipette method after $\mathrm{OM}$ destruction with $\mathrm{H}_{2} \mathrm{O}_{2}$ and $\mathrm{Na}$ citrate dispersion of clay.

Total trace metal concentrations were measured on bulk samples (one per $1 \mathrm{~m}^{2}$ plot) by tri-acid $\left(\mathrm{HCl} \mathrm{37 \% ,} \mathrm{HNO}_{3}\right.$ $65 \%$, HF $40 \%$ ) attack of finely ground soil samples on a hot plate at $70{ }^{\circ} \mathrm{C}$ during $48 \mathrm{~h}$. The dry residue was redissolved with $1 \mathrm{~mL} \mathrm{HNO} \mathrm{HN}_{3} 65 \%$ in a volume of $30 \mathrm{~mL}$ and total element concentrations were determined by ICP-OES (Varian VistaMPX). The method was checked with a certified reference soil material (SRM 2711a, Montana II Soil).

\section{Plant analysis}

The four individuals used for elemental composition were thoroughly washed once with tap water and twice with deionized water. Samples were then dried at $65^{\circ} \mathrm{C}$ for $48 \mathrm{~h}$ and ground. Subsamples of $0.4 \mathrm{~g}$ were dry-ashed during $12 \mathrm{~h}$ at $500{ }^{\circ} \mathrm{C}$ and dissolved with concentrated $\mathrm{HNO}_{3}(65 \%)$. Concentrations in $\mathrm{Zn}, \mathrm{Cd}, \mathrm{Cu}, \mathrm{Ni}, \mathrm{Pb}$, and major elements (expressed as $\mu \mathrm{g} \mathrm{g}^{-1}$ of $105^{\circ} \mathrm{C}$-dried plant) were determined with ICP-OES (Varian, Vista-MPX). Analytical method was checked on NIST standard reference (SRM 1547, Peach leaves).

\section{Statistical analysis}

Data were Box-Cox transformed to meet the assumptions of normality of residuals and homoscedasticity between groups. Soil parameters were analyzed for each site separately using the two-way factorial ANOVA to test for the effect of soil treatments and possible differences between blocks. Variations of biomass, plant elemental concentrations, and metal masses in plants were analyzed using the three-way ANOVA for each site with populations, soil treatments, and blocks as fixed factors. Post hoc comparisons were performed using the Tukey HSD test. Comparisons between soil concentrations in trace metals before and after plant cultivation were conducted using the Student's paired $t$ tests.

In order to test for the influence of soil parameters on biomass production and metal uptake, linear models were constructed using both factors (population and site) and continuous variables $(\% \mathrm{OM}$, texture, exchangeable concentrations in trace metals and $\mathrm{Ca}, \mathrm{K}, \mathrm{Mg}, \mathrm{P}$ ). All soil variable combinations that respected the assumption of non-collinearity (Variance Inflation factor $((\mathrm{VIF})<10)$ was introduced in linear models. CEC and $\mathrm{pH}$ were not introduced as variables in the models because of their multivariate nature (multiple influence on soil chemistry), and because $\mathrm{pH}$ values within sites are very homogeneous and particularly high (7-8) which is already known to be detrimental for metal accumulation (Wang et al. 2006; Yanai et al. 2006). Since total biomass is strongly influenced by unwanted mortality (herbivory), we chose to test for the

Table 1 Soil trace metal concentrations (total and ammonium acetate-EDTA extraction) before cultivation, among treatments (Comp. compost addition, Fert. fertilizer, Cont. control) and blocks

\begin{tabular}{|c|c|c|c|c|c|c|c|c|c|c|c|c|}
\hline & & & \multicolumn{2}{|c|}{$\mathrm{Cd}\left(\mathrm{mg} \mathrm{kg}^{-1}\right)$} & \multicolumn{2}{|c|}{$\mathrm{Cu}\left(\mathrm{mg} \mathrm{kg}^{-1}\right)$} & \multicolumn{2}{|c|}{$\mathrm{Ni}\left(\mathrm{mg} \mathrm{kg}^{-1}\right)$} & \multicolumn{2}{|l|}{$\mathrm{Pb}\left(\mathrm{mg} \mathrm{kg}^{-1}\right)$} & \multicolumn{2}{|c|}{$\mathrm{Zn}\left(\mathrm{mg} \mathrm{kg}^{-1}\right)$} \\
\hline & & & $\mathrm{T}$ & $\begin{array}{l}\text { Ac. } \\
\text { EDTA }\end{array}$ & Total & $\begin{array}{l}\text { Ac. } \\
\text { EDTA }\end{array}$ & Total & $\begin{array}{l}\text { Ac. } \\
\text { EDTA }\end{array}$ & Total & $\begin{array}{l}\text { Ac. } \\
\text { EDTA }\end{array}$ & Total & $\begin{array}{l}\text { Ac. } \\
\text { EDTA }\end{array}$ \\
\hline \multirow[t]{7}{*}{ GR } & \multirow[t]{3}{*}{ Treatment } & Comp. & $1.4(0.2)^{\mathrm{a}}$ & $0.85(0.06)^{\mathrm{a}}$ & $150(40)^{\mathrm{a}}$ & $36(3)^{\mathrm{a}}$ & $36(6)^{\mathrm{a}}$ & $1.6(0.1)^{\mathrm{a}}$ & $480(180)^{\mathrm{a}}$ & $160(30)^{\mathrm{a}}$ & $410(50)^{\mathrm{a}}$ & $138(8)^{\mathrm{a}}$ \\
\hline & & Fert. & $2.1(0.7)^{\mathrm{a}}$ & $1.02(0.08)^{\mathrm{b}}$ & $190(60)^{\mathrm{ab}}$ & $52(6)^{\mathrm{ab}}$ & $46(11)^{\mathrm{b}}$ & $2.3(0.1)^{\mathrm{b}}$ & $1800(1400)^{\mathrm{a}}$ & $300(80)^{\mathrm{b}}$ & $550(130)^{\mathrm{a}}$ & $164(14)^{\mathrm{a}}$ \\
\hline & & Cont. & $1.7(0.4)^{\mathrm{a}}$ & $1.11(0.12)^{\mathrm{b}}$ & $180(60)^{\mathrm{b}}$ & $54(5)^{\mathrm{b}}$ & $44(10)^{\mathrm{b}}$ & $2.3(0.1)^{\mathrm{b}}$ & $900(500)^{\mathrm{a}}$ & $280(60)^{\mathrm{b}}$ & $480(80)^{\mathrm{a}}$ & $160(10)^{\mathrm{a}}$ \\
\hline & \multirow[t]{4}{*}{ Block } & 1 & $2.5(0.3)^{\mathrm{a}}$ & $1.48(0.11)^{\mathrm{a}}$ & $310(30)^{\mathrm{a}}$ & $73(5)^{\mathrm{a}}$ & $65(8)^{\mathrm{a}}$ & $2.1(0.2)^{\mathrm{b}}$ & $3200\left(1500^{\mathrm{a}}\right)$ & $620(60)^{\mathrm{a}}$ & $720(110)^{\mathrm{a}}$ & $218(11)^{\mathrm{a}}$ \\
\hline & & 2 & $2.5(0.6)^{\mathrm{a}}$ & $1.00(0.04)^{\mathrm{b}}$ & $200(20)^{\mathrm{b}}$ & $51(3)^{\mathrm{b}}$ & $47(3)^{\mathrm{b}}$ & $2.2(0.2)^{\mathrm{ab}}$ & $450(20)^{\mathrm{b}}$ & $125(5)^{\mathrm{c}}$ & $470(30)^{\mathrm{a}}$ & $135(4)^{b}$ \\
\hline & & 3 & $1(0.1)^{\mathrm{b}}$ & $0.84(0.03)^{\mathrm{c}}$ & $100(10)^{\mathrm{c}}$ & $39(4)^{c}$ & $30(1)^{\mathrm{c}}$ & $2.5(0.1)^{\mathrm{a}}$ & $240(10)^{\mathrm{c}}$ & $85(4)^{\mathrm{d}}$ & $360(4)^{b}$ & $137(7)^{b}$ \\
\hline & & 4 & $1(0.1)^{\mathrm{b}}$ & $0.66(0.02)^{\mathrm{d}}$ & $80(10)^{\mathrm{c}}$ & $26(1)^{\mathrm{d}}$ & $25(2)^{\mathrm{d}}$ & $1.6(0.1)^{\mathrm{c}}$ & $390(90)^{\mathrm{bc}}$ & $160(14)^{\mathrm{b}}$ & $370(26)^{\mathrm{b}}$ & $127(4)^{b}$ \\
\hline \multirow[t]{7}{*}{ MAS } & \multirow[t]{3}{*}{ Treatment } & Comp. & $2(0.4)^{\mathrm{a}}$ & $0.50(0.02)^{\mathrm{a}}$ & $230(80)^{\mathrm{a}}$ & $39(2)^{\mathrm{a}}$ & $34(3)^{\mathrm{a}}$ & $0.8(0.1)^{\mathrm{a}}$ & $430(30)^{\mathrm{a}}$ & $100(4)^{\mathrm{a}}$ & $530(50)^{\mathrm{a}}$ & $77(6)^{\mathrm{a}}$ \\
\hline & & Fert. & $1.7(0.2)^{\mathrm{a}}$ & $0.56(0.03)^{\mathrm{ab}}$ & $180(10)^{\mathrm{a}}$ & $48(4)^{\mathrm{b}}$ & $43(5)^{\mathrm{a}}$ & $0.9(0.2)^{\mathrm{a}}$ & $440(30)^{\mathrm{a}}$ & $125(10)^{\mathrm{b}}$ & $630(70)^{\mathrm{a}}$ & $90(8)^{\mathrm{ab}}$ \\
\hline & & Cont. & $2.2(0.3)^{\mathrm{a}}$ & $0.66(0.05)^{\mathrm{b}}$ & $230(20)^{\mathrm{a}}$ & $53(3)^{\mathrm{b}}$ & $43(3)^{\mathrm{a}}$ & $1.2(0.2)^{\mathrm{b}}$ & $500(30)^{\mathrm{a}}$ & $135(10)^{\mathrm{b}}$ & $710(70)^{\mathrm{a}}$ & $97(8)^{\mathrm{b}}$ \\
\hline & \multirow[t]{4}{*}{ Block } & 1 & $1.9(0.1)^{\mathrm{a}}$ & $0.53(0.02)^{\mathrm{ab}}$ & $190(30)^{\mathrm{a}}$ & $51(6)^{\mathrm{a}}$ & $35(2)^{\mathrm{a}}$ & $0.7(0.2)^{\mathrm{a}}$ & $460(10)^{\mathrm{a}}$ & $130(10)^{\mathrm{a}}$ & $590(50)^{\mathrm{a}}$ & $89(6)^{\mathrm{b}}$ \\
\hline & & 2 & $2.1(0.3)^{\mathrm{a}}$ & $0.68(0.06)^{\mathrm{c}}$ & $160(10)^{\mathrm{a}}$ & $43(3)^{\mathrm{a}}$ & $42(7)^{\mathrm{a}}$ & $0.8(0.1)^{\mathrm{a}}$ & $450(40)^{\mathrm{a}}$ & $120(10)^{\mathrm{a}}$ & $690(80)^{\mathrm{a}}$ & $90(6)^{b}$ \\
\hline & & 3 & $2.4(0.3)^{\mathrm{a}}$ & $0.62(0.03)^{\mathrm{bc}}$ & $310(90)^{\mathrm{a}}$ & $47(3)^{\mathrm{a}}$ & $47(3)^{\mathrm{a}}$ & $1.8(0.1)^{\mathrm{b}}$ & $520(30)^{\mathrm{a}}$ & $140(10)^{\mathrm{a}}$ & $740(60)^{\mathrm{a}}$ & $117(6)^{\mathrm{a}}$ \\
\hline & & 4 & $1.4(0.1)^{\mathrm{a}}$ & $0.47(0.03)^{\mathrm{a}}$ & $180(20)^{\mathrm{a}}$ & $45(3)^{\mathrm{a}}$ & $37(4)^{\mathrm{a}}$ & $0.6(0.05)^{\mathrm{a}}$ & $390(30)^{\mathrm{a}}$ & $88(4)^{\mathrm{b}}$ & $480(40)^{\mathrm{a}}$ & $56(3)^{\mathrm{c}}$ \\
\hline
\end{tabular}

Values are means and values in parentheses are the standard errors of the mean ( $n=3$ to 16). Different superscript letters indicate significant differences between treatments or blocks at the $P<0.05$ level. Results of the analyses of variance are found in the supporting information (Table S2) 
influence of soil parameters on mean individual biomass (instead of total biomass).

Based on the Bayesian information criterion (BIC) (a more parsimonious alternative to Akaike information criterion), the most parsimonious model was selected for each response variable. The relative contribution of factors and selected variables were then calculated using LMG, the $R^{2}$ contribution averaged over orderings among regressors (Kruskal 1987), with R package relaimpo (Grömping 2006).

All statistical analyses were carried out with the R statistical software v. 3.1.2 (R Development Core Team 2015).

\section{Results}

\section{Soil characteristics}

Table 1 presents total and exchangeable $\left(\mathrm{NH}_{4}\right.$ acetate - EDTA) concentrations of trace metals in soils. Soil concentrations in $\mathrm{Cd}, \mathrm{Cu}, \mathrm{Pb}$, and $\mathrm{Zn}$ measured at GR and MAS sites are above regional thresholds for parks, natural areas, and agricultural lands $\left(2,120,200\right.$, and $333 \mathrm{mg} \mathrm{kg}^{-1}$ for $\mathrm{Cd}, \mathrm{Cu}, \mathrm{Pb}$, and $\mathrm{Zn}$, respectively) (Brussels Government 2009). For both sites, soil $\mathrm{Pb}$ and $\mathrm{Zn}$ concentrations exceeded regional thresholds in the four blocks. For $\mathrm{Cd}$ and $\mathrm{Cu}$, soil concentrations exceeded regional thresholds in at least two out of four blocks in both sites.

The soil treatments (compost or fertilizer addition) had little or no effect on total soil metal concentrations but significantly influenced the exchangeable fraction (Table 1 and Table S2). A significant decrease in exchangeable forms of the four trace metals considered was measured in the compost treatment compared to the control $(-24 \% \mathrm{Cd},-26$ up to $-33 \% \mathrm{Cu},-26$ up to $-43 \% \mathrm{~Pb},-14$ up to $-20 \% \mathrm{Zn}$ ). These results can be partly attributed to the diluting effect of the application of compost, but this would account for max $10 \%$ of this decrease. The immobilizing effect of organic matter is expected to be responsible for the rest of this decrease (Beesley et al. 2010).

There was no effect of fertilizers' application on soil fertility parameters (Table 2 and Table S3), probably because the quantity applied was much too low. The application of compost led to significantly higher $\mathrm{CEC}$; exchangeable $\mathrm{K}, \mathrm{Mg}$, and $\mathrm{P}$ contents in both sites; and to higher $\mathrm{pH}$ and $\mathrm{Ca}$ content at GR site.

\section{Biomass: effects of soil treatment and population}

The average yields of $N$. caerulescens dry biomass grown at sites GR and MAS were $2.55 \pm 1.38$ (mean $\pm \mathrm{SD}$ ) $\mathrm{t} \mathrm{ha}^{-1}$ and $1.16 \pm 0.62 \mathrm{t} \mathrm{ha}^{-1}$, respectively. GAN population yielded a lower biomass than NMET populations at both sites, although not significantly different at MAS (Fig. 1; Table S1). In GR, GAN biomass was two times lower compared to NMET biomass. GAN plants had on average lower survival rates (GR, $52 \pm 30 \%$; MAS, $52 \pm 27 \%$ ), at

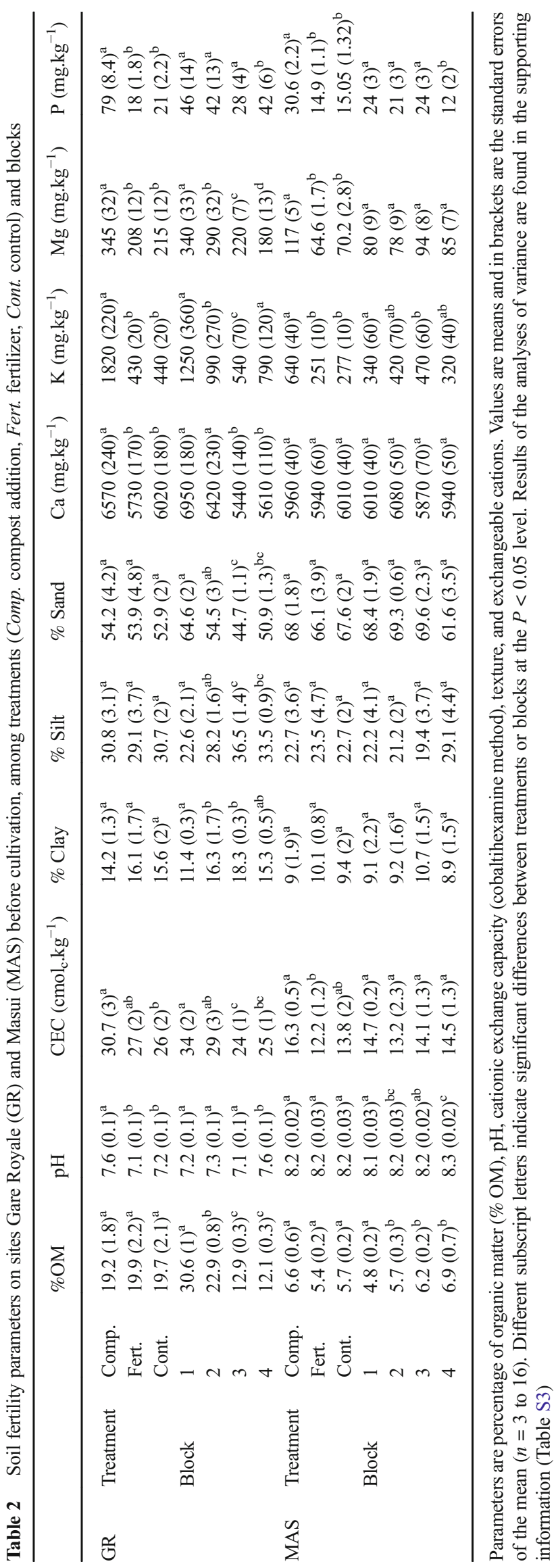



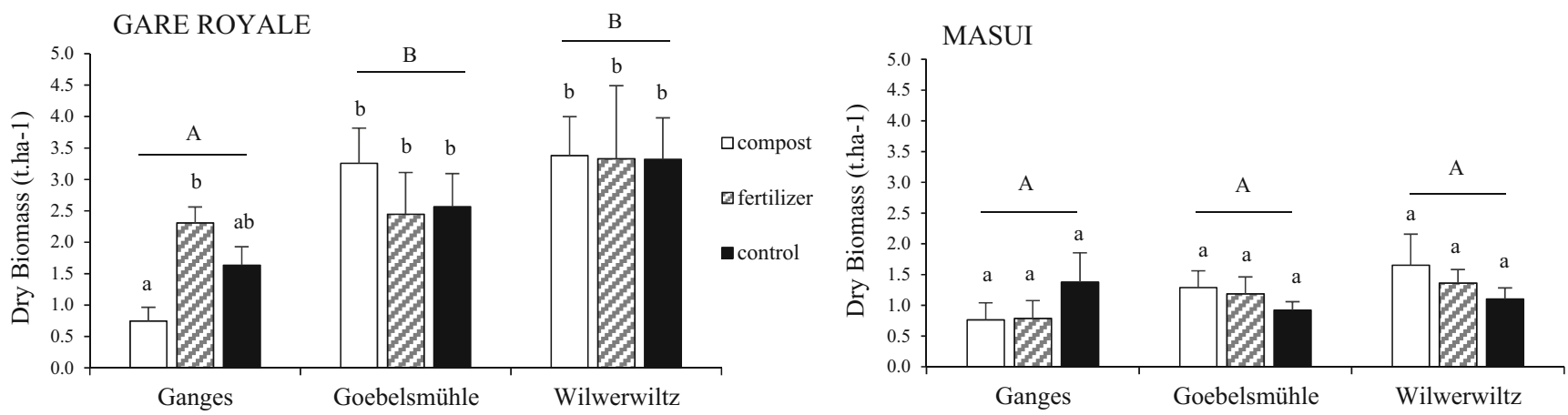

Fig. 1 Dry biomass of $N$. caerulescens plants coming from three origins (Ganges, Goebelsmühle, Wilwerwiltz), grown on three soil treatments (compost, fertilizer, and control) at site Gare Royale and site Masui.

Means with different letters indicate significant difference between populations (uppercase) and treatments (lowercase) at the $P<0.05$ level. The error bars are standard errors

GARE ROYALE

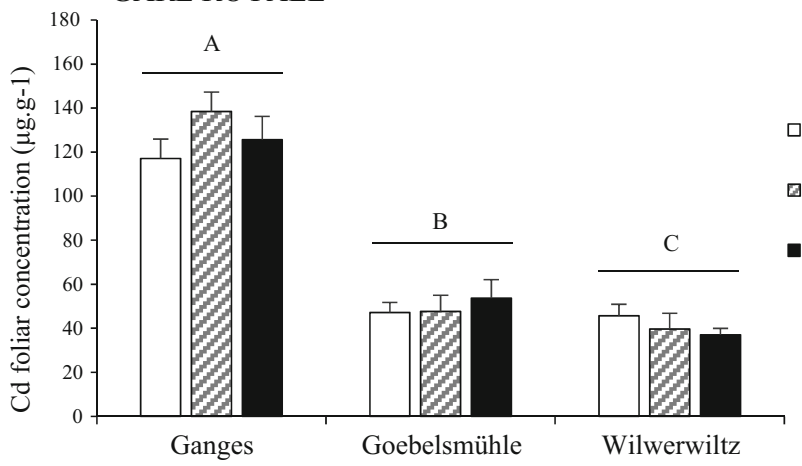

GARE ROYALE

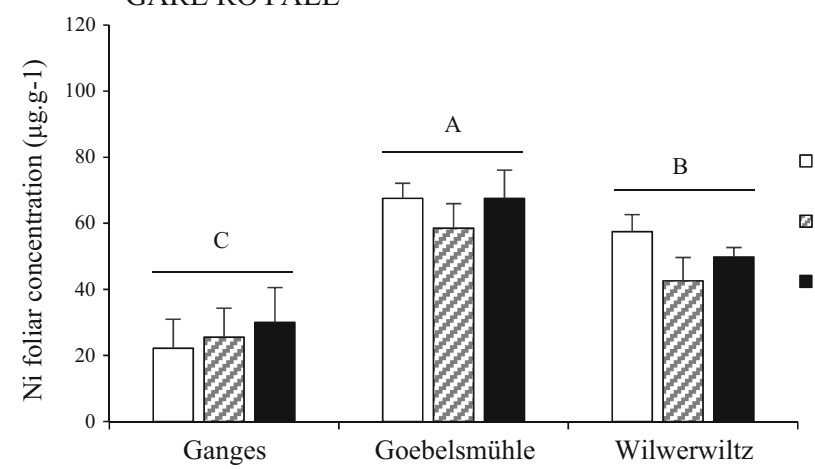

GARE ROYALE

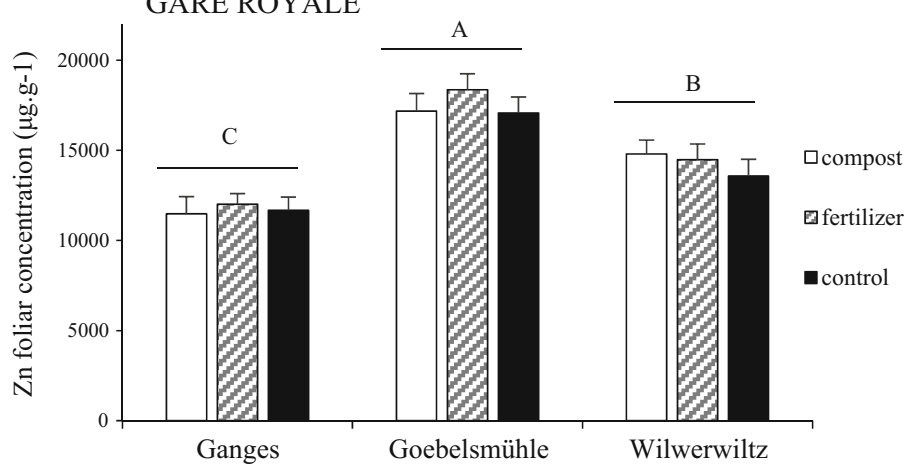

Fig. 2 Trace metal concentrations (Cd, Ni, $\mathrm{Zn})$ in the shoots of N. caerulescens plants coming from three origins (GAN, GOE, WIL), grown on three soil treatments (compost, fertilizer, and control) at site Gare Royale and site Masui. Means with different letters indicate
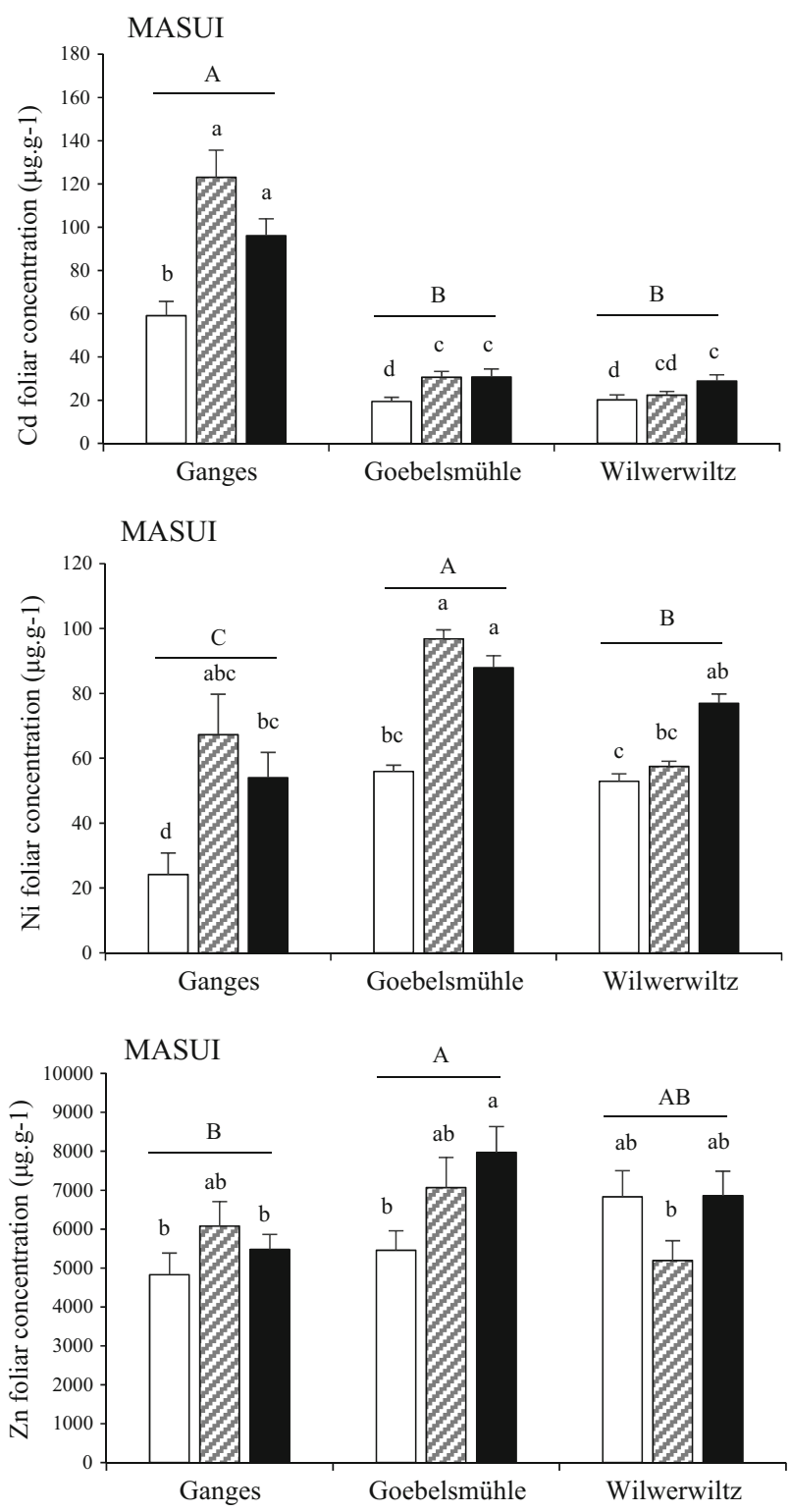

significant difference between populations (uppercase) and treatments (lowercase) at the $P<0.05$ level. There were no significant differences between treatments at GR. The error bars are standard errors 
both sites compared to NMET plants (GR: GOE $72 \pm 19 \%$, WIL $72 \pm 24 \%$; MAS GOE $69 \pm 12 \%$, WIL $67 \pm 26 \%$ ) but the difference was not significant.

The treatment (addition of fertilizer or compost) had no general significant effect on plant biomass production (Fig. 1). Results show however a negative effect of compost on GAN biomass at GR. As the individual biomass of GAN was not affected by compost addition $(P>0.05)$, it seems that the compost mainly impacted the survival of GAN plants. Plant biomass also varies significantly between blocks in both sites due to a large heterogeneity of soil conditions (trace metal contents and physico-chemical properties) (Tables 1 and 2).

\section{Metal concentrations in plants}

Concentrations of Cd, $\mathrm{Ni}$, and $\mathrm{Zn}$ in N. caerulescens plants for each population and treatment are shown in Fig. 2. Foliar concentrations in all trace metals were significantly different depending on the block (Table 3), which is explained by the significant heterogeneity in soil metal concentrations among blocks (Table 2) expected in field experiments.

\section{Effect of population}

Populations had significantly different foliar concentrations in $\mathrm{Cd}, \mathrm{Ni}$, and $\mathrm{Zn}$ in both sites (Fig. 2 and
Table 3). Cadmium concentration in GAN shoots (128 $\mu \mathrm{g} \mathrm{g}^{-1}$ at GR and $92 \mu \mathrm{g} \mathrm{g}^{-1}$ at MAS) was about three times higher than in NMET populations $\left(45 \mu \mathrm{g} \mathrm{g}^{-1}\right.$ at GR and $25 \mu \mathrm{g} \mathrm{g}^{-1}$ at MAS). In contrast, NMET populations accumulated about 1.2-1.8 (WIL) and 1.2-2.3 (GOE) times more $\mathrm{Zn}$, and about 1.3-2 (WIL) and 1.72.5 (GOE) times more Ni compared to GAN (shoot concentrations in $\left.\mu \mathrm{g} \mathrm{g}^{-1}\right)$.

$\mathrm{Cu}$ and $\mathrm{Pb}$ concentrations were all relatively low but slightly higher in GAN plants (respectively, $12 \pm 5$ and $4 \pm 4{\mu \mathrm{g} \mathrm{g}^{-1}}^{-1}$ at GR, $22 \pm 8$ and $7 \pm 3 \mu \mathrm{g} \mathrm{g}^{-1}$ at MAS) compared to NMET populations $\left(6 \pm 3\right.$ and $3 \pm 3 \mu \mathrm{g} \mathrm{g}^{-1}$ at GR, $14 \pm 5$ and $5 \pm 2 \mu \mathrm{g} \mathrm{g}^{-1}$ at MAS) in both sites.

\section{Effect of soil treatment}

The application of fertilizers did not influence trace metal concentration in plants. In contrast, compost addition had a negative effect on concentrations of $\mathrm{Cd}, \mathrm{Ni}$, and $\mathrm{Zn}$ at MAS site, for all three populations but this decreasing effect was most striking on GAN (e.g., Cd $96 \mu \mathrm{g} \mathrm{g}^{-1}$ on control vs $59 \mu \mathrm{g} \mathrm{g}^{-1}$ with compost, Fig. 2). At GR, compost addition had the same negative effect on GAN but on metal uptake of $\mathrm{Cd}, \mathrm{Ni}$, and $\mathrm{Zn}$ $\left(\mathrm{kg} \mathrm{ha}^{-1}\right)$, while it slightly increased metal extraction of NMET populations.
Table 3 Analysis of variance of foliar concentrations in trace metals of three population of $N$. caerulescens (one calamine, Ganges, and two nonmetallicolous, Wilwerwiltz and Goebelsmühle) grown on three soil treatments (control soil, fertilizer, compost) in two experimental sites $(\mathrm{GR}=$ Gare Royale and MAS = Masui $)$. For each factor
$($ Pop. $=$ population, Treat. $=$ Treatment, Block $)$ and interactions, the number of degrees of freedom (d.f.), mean square (MS), $F$ value, and level of significance associated $(* * * P<0.001$; $* * P<0.01 ; * P<0.05$; $\cdot P<0.1 ; n s$, not significant) are given

\begin{tabular}{|c|c|c|c|c|c|c|c|c|c|c|}
\hline & & \multicolumn{3}{|c|}{ Foliar concentration in $\mathrm{Cd}$} & \multicolumn{3}{|c|}{ Foliar concentration in $\mathrm{Ni}$} & \multicolumn{3}{|c|}{ Foliar concentration in $\mathrm{Zn}$} \\
\hline & & d.f. & MS & $F$ & d.f. & MS & $F$ & d.f. & MS & $F$ \\
\hline \multirow[t]{8}{*}{ GR } & Pop. & 2 & 113 & $332 * * *$ & 2 & 4.16 & $86.13 * * *$ & 2 & 19,735 & $47.8 * * *$ \\
\hline & Treat. & 2 & 0.13 & $0.38^{\mathrm{ns}}$ & 2 & 0.17 & $3.53 *$ & 2 & 242 & $0.59^{\mathrm{ns}}$ \\
\hline & Block & 3 & 28.6 & $84 * * *$ & 3 & 6.92 & $143.4 * * *$ & 3 & 4313 & $10.4 * * *$ \\
\hline & Pop. $\times$ treat. & 4 & 1.4 & $4.3^{* *}$ & 4 & 0.23 & $4.6^{* *}$ & 4 & 146 & $0.35^{\mathrm{ns}}$ \\
\hline & Pop. $\times$ block & 6 & 1.7 & $5.0 * * *$ & 6 & 0.42 & $8.79 * * *$ & 6 & 841 & 2.04 \\
\hline & Treat. $\times$ block & 6 & 1.4 & $4.0^{* *}$ & 6 & 0.27 & $5.55^{* * *}$ & 6 & 275 & $0.67^{\mathrm{ns}}$ \\
\hline & Pop. $\times$ treat. $\times$ block & 12 & 2.1 & $6.2 * * *$ & 12 & 0.09 & $1.92 *$ & 12 & 486 & $1.18^{\mathrm{ns}}$ \\
\hline & Residuals & 95 & 0.34 & & 92 & 0.05 & & 94 & 413 & \\
\hline \multirow[t]{8}{*}{ MAS } & Pop. & 2 & 2.56 & $167 * * *$ & 2 & 16.8 & $16.2 * * *$ & 2 & 6186 & $4.44 *$ \\
\hline & Treat. & 2 & 0.345 & $22.4 * * *$ & 2 & 45.2 & $43.6^{* * *}$ & 2 & 5488 & $3.94 *$ \\
\hline & Block & 3 & 0.140 & $9.05^{* * *}$ & 3 & 92.2 & $88.8^{* * *}$ & 3 & 18,607 & $13.34 * * *$ \\
\hline & Pop. $\times$ treat. & 4 & 0.023 & $1.54^{\mathrm{ns}}$ & 4 & 5.95 & $5.73 * * *$ & 4 & 4461 & $3.20 *$ \\
\hline & Pop. $\times$ block & 6 & 0.033 & 2.18 . & 6 & 4.86 & $4.68 * * *$ & 6 & 4570 & $3.28 * *$ \\
\hline & Treat. $\times$ block & 6 & 0.063 & $4.14 * * *$ & 6 & 5.51 & $5.31 * * *$ & 6 & 3376 & $2.42 *$ \\
\hline & Pop. $\times$ Treat. $\times$ block & 11 & 0.017 & $1.13^{\mathrm{ns}}$ & 11 & 2.84 & $2.73 * *$ & 11 & 2815 & $2.02 *$ \\
\hline & Residuals & 97 & 0.015 & & 99 & 1.04 & & 98 & 1394 & \\
\hline
\end{tabular}


Metal uptake

Cd uptake is highest for GAN plants $\left(0.20 \pm 0.12 \mathrm{~kg} \mathrm{ha}^{-1}\right.$ at GR, $0.10 \pm 0.07 \mathrm{~kg} \mathrm{ha}^{-1}$ at MAS) compared to NMET populations $\left(0.14 \pm 0.11 \mathrm{~kg} \mathrm{ha}^{-1}\right.$ at GR, $0.03 \pm 0.02 \mathrm{~kg} \mathrm{ha}^{-1}$ at MAS). It is interesting to notice that $\mathrm{Cd}$ uptake by NMET at GR is higher than GAN uptake at MAS. Ni and Zn uptakes are on the other hand higher for NMET populations (Ni $0.20 \pm 0.18 \mathrm{~kg} \mathrm{ha}^{-1}$ at GR, $0.08 \pm 0.07 \mathrm{~kg} \mathrm{ha}^{-1}$ at MAS; Zn $47 \pm 24 \mathrm{~kg} \mathrm{ha}^{-1}$ at GR, $7.9 \pm 5.4 \mathrm{~kg} \mathrm{ha}^{-1}$ at MAS) compared to GAN plants (Ni $0.04 \pm 0.04 \mathrm{~kg} \mathrm{ha}^{-1}$ at GR, $0.05 \pm 0.05 \mathrm{~kg} \mathrm{ha}^{-1}$ at MAS; Zn $18 \pm 10 \mathrm{~kg} \mathrm{ha}^{-1}$ at GR, $5.9 \pm 4.1 \mathrm{~kg} \mathrm{ha}^{-1}$ at MAS).

Metal uptake by $N$. caerulescens after 6.5 months of growth resulted into significant decreases in exchangeable concentrations of trace metals in the soils only at GR (paired $t$ test performed on concentrations measured in soils sampled before and after the culture, $n=36, t=8.3, P<0.001$ ): $23 \%$ less $\mathrm{Cd}$ and $31 \%$ less $\mathrm{Zn}$ on average (see details in supplementary Table S4). In the unplanted subplot within the $1 \mathrm{~m}^{2}$ plot, the decreases were 10 and $13 \%$ for $\mathrm{Cd}$ and $\mathrm{Zn}$. At MAS, however, there was a significant overall increase in exchangeable $\mathrm{Zn}$ by $13 \%(P<0.05)$ and by $10 \%$ for $\mathrm{Cd}$ $(P=0.07)$.

\section{Soil influence on plant biomass and concentrations}

Results of the explanatory models are presented in Table 4. Across the two sites, clay content positively influences (19\%) individual biomass production, while site specificity alone (factor site in the model) explains $25 \%$ of the variation. Soil exchangeable $\mathrm{Zn}$ at MAS enhances biomass production (28\%) while at GR, $\mathrm{Pb}$ and/or $\mathrm{Zn}$ (correlation between variables $r=0.94$ ) negatively influence it, but only for NMET populations. The part of biomass variance explained by the population factor is relatively limited across the two sites (8\%) while at GR, it accounts for a more significant part of the variation $(26 \%)$.

Across both sites, variation of shoot concentration in $\mathrm{Cd}$ is mostly explained by the population effect $(50 \%)$ while site $(7 \%)$, soil $\mathrm{Cd}(9 \%)$, and $\mathrm{Pb}(5 \%)$ explain together about $20 \%$ of the variance. When MET and NMET populations are considered separately, soil $\mathrm{Cd}$ concentration accounts for 28 and $17 \%$ of the variance, respectively. Variation of shoot concentration in $\mathrm{Zn}$ is however mostly explained by site $(21 \%)$ or soil parameters $(44 \%)$ among which OM (18\%), clay content $(13 \%)$, and soil $\mathrm{Zn}$ concentration $(10 \%)$ while the population factor explains only about $6 \%$ of the variation. Again at GR, population effect accounts for a more significant part of the variation (37\%).

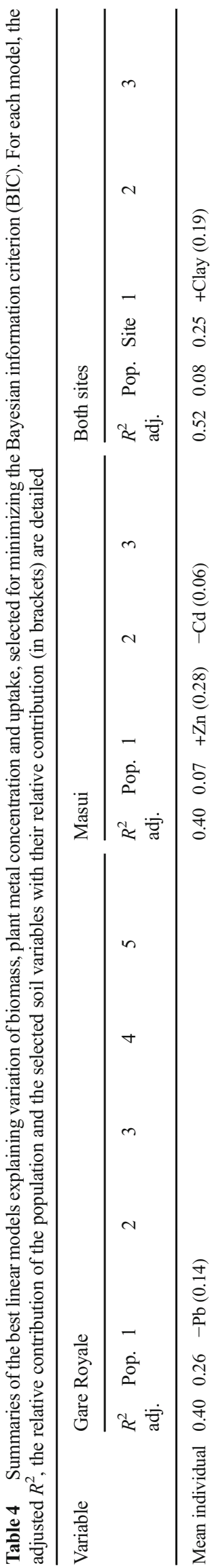

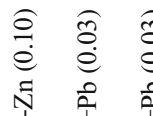

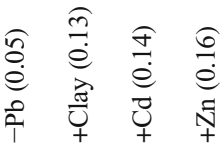

ล $\cong$ ก

¿

U † 巳

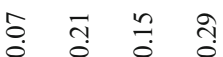

ก

+

$\begin{array}{llll}1 & 0 & 0 & 0\end{array}$

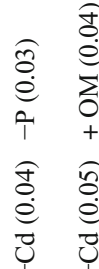

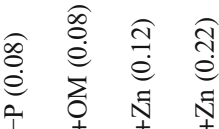

¿. ठ․ ڤे है

@ I ñ थे

?ํ.

巳ே 


\section{Discussion}

\section{MET and NMET populations for phytoextraction}

Our trials yielded a quite remarkable biomass production at GR with $2.55 \mathrm{t} \mathrm{ha}^{-1}$ of dry biomass on average and up to $5 \mathrm{t} \mathrm{ha}^{-1}$ for NMET on the best plot. These results are globally coherent with other field studies with average reported yields of $1-2 \mathrm{t} \mathrm{ha}^{-1}$ and max. of $4 \mathrm{t} \mathrm{ha}^{-1}$ (Hammer and Keller 2003; Maxted et al. 2007; McGrath et al. 2006; Simmons et al. 2015). So far, as underlined by Simmons et al. (2015), the initial yield predictions of 5 to $10 \mathrm{t} \mathrm{ha}^{-1}$ (Zhao et al. 2003) had not been supported by any field trials. Similar yield assumptions had also been made based on individual biomass with theoretical extrapolations of one harvest on three successive crops in the same season (Hammer and Keller 2003; Maxted et al. 2007) which seems highly unreasonable given the difficult establishment of seedlings late in the season. Even if yields of $10 \mathrm{t} \mathrm{ha}^{-1}$ are most likely unrealistic for field conditions, our trials show that NMET populations can produce up to $5 \mathrm{t} \mathrm{ha}^{-1}$ of dry biomass in one harvest in certain conditions, which is the best yield obtained so far in 6 months of growth.

The comparison of GAN and NMET populations in terms of biomass production gives an advantage to the latter, mostly in good growth conditions (around two times more at GR site). With lower survival, GAN (survival rate $52 \%$ ) appears first to be clearly more sensitive to herbivore pressure than NMET (survival rate $70 \%$ ) as had already been demonstrated in the field (Noret et al. 2007). Secondly, our results show a tendency for NMET plants to produce greater individual biomass (at GR, 1.5 times more than GAN). This might be explained by the difference of dominant natural life cycle of the two ecotypes: annual for CAL (GAN) while NMET from Luxemburg are mostly short-lived perennials (Dubois 2005; Dechamps et al. 2011). With a longer vegetative growth prior to flowering, NMET from Luxemburg may therefore have an advantage in terms of biomass production. It would however be relevant to confirm this by performing a field trial in a growth cycle following the dominant natural cycle of the plant (germination in autumn, vernalization, flowering and harvest in late spring/ early summer). In sum, while most studies focus on the use of CAL populations (Koopmans et al. 2008; Maxted et al. 2007; McGrath et al. 2006), the relative advantage of NMET populations for biomass production and resistance to herbivory should be taken into account and further studied.

GAN population was, as expected (Zhao et al. 2003), a better performer for $\mathrm{Cd}$ phytoextraction. With $\mathrm{Cd}$ shoot concentrations about two to three times higher than in
NMET plants in our essays, the advantage of the high Cd CAL populations from South of France in terms of $\mathrm{Cd}$ accumulation is clear. Although $\mathrm{Cd}$ is generally the main target element with phytoextraction, $\mathrm{Zn}$ is also an element of environmental concern which should also be considered when evaluating the efficiency of phytoextraction with $N$. caerulescens. Numerous urban sites contaminated with trace metals are above thresholds for $\mathrm{Zn}$ in Brussels as other urban areas in the world (Imperato et al. 2003; Kachenko and Singh 2006; Li et al. 2001). This study has confirmed for the first time in field trials the interest of using NMET populations of $N$. caerulescens for $\mathrm{Zn}$ phytoextraction. Their higher potential for $\mathrm{Zn}$ extraction had already been shown (Meerts and van Isacker 1997; Escarré et al. 2000) but had never been tested in the field. The average metal uptake of NMET was $27 \mathrm{~kg} \mathrm{Zn} \mathrm{ha}^{-1}$, compared to $11 \mathrm{~kg} \mathrm{Zn} \mathrm{ha}^{-1}$ for GAN. The advantage of the NMET ecotype over GAN appears more markedly at GR with the highly available $\mathrm{Zn}$ content in the soil and higher plant accumulation. At MAS with higher mortality and lower Zn bioavailability, the difference between GAN and NMET is still significant but less pronounced.

Comparing phytoextraction efficiency with previous field trials is difficult because of the variability of soil conditions, cultural practices, and lengths of growth (from 2 to 14 months). However, metal uptake is still mostly dependent on soil metal concentrations as can be seen when plotting $\mathrm{Cd}$ and $\mathrm{Zn}$ uptake versus corresponding soil concentrations from this study and selected field trials from the literature which all used the GAN ecotype (for similar initial concentrations, i.e., $\mathrm{Cd}<10 \mathrm{mg} \mathrm{kg}{ }^{-1}, \mathrm{Zn}$ $<1200 \mathrm{mg} \cdot \mathrm{kg}^{-1}$ ) (Hammer and Keller 2003; Maxted et al. 2007; McGrath et al. 2006) (Fig. 3). This comparison shows first that in spite of the advantage of GAN population for Cd extraction (e.g., at GR 0.20 vs $0.14 \mathrm{~kg} \mathrm{ha}^{-1}$ for NMET), initial soil concentration is the main determining factor of the level of Cd uptake. The advantage of NMET on GAN for Zn uptake occurs particularly at GR where GAN uptake is slightly above the general trend while NMET uptake is markedly higher than in any other field trial with GAN (Fig. 3). The dependence of Zn uptake on the initial soil concentration is also clear though with more variability probably explained by differences in bioavailability.

The results of our comparison of CAL and NMET ecotypes suggest interesting research perspectives in terms of population or cultivar selection. It appears that life history traits and the adaptation to biotic pressure are as much relevant as metal-related traits (e.g., accumulation), and that all should be considered when trying to select for ideotypes for phytoextraction. There is a clear interest in selecting, for example, for higher individual biomass 


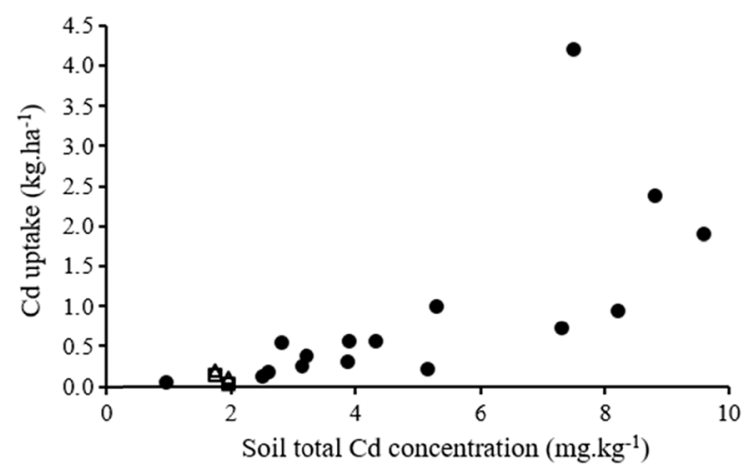

Fig. 3 Metal uptakes of Noccaea caerulescens as a function of $\mathrm{Cd}$ and $\mathrm{Zn}$ soil concentrations. Data were collected from the three main field trials found in the literature (solid circles) with soil concentrations $\mathrm{Cd}$ $<10 \mathrm{mg} \mathrm{kg}^{-1}, \mathrm{Zn}<1200 \mathrm{mg} \mathrm{kg}^{-1}$ (Hammer and Keller $2003 n=2$,

among and within populations judged most suitable for phytoextraction, given the large inter- and intra-pop variation in biomass production (Meerts and van Isacker 1997; Molitor et al. 2005). Furthermore, considering the relative genetic proximity between MET and NMET populations from South of France within one divergent genetic unit (Jiménez-Ambriz et al. 2007; Gonneau et al. 2017), it can be expected that the latter accumulate more $\mathrm{Cd}$ than NMET from Luxemburg, even if it is still less than GAN population (Escarré et al. 2000). With the relative advantage of the NMET ecotype in terms of suitability for field conditions with moderate soil contamination, it may then be worth testing NMET populations from South of France for $\mathrm{Cd}$ phytoextraction to combine advantages of high $\mathrm{Cd}$ accumulation and resistance to biotic stress.

\section{Effect of soil amendment}

The addition of compost had mostly negative effects on the phytoextraction efficiency. In addition to a slight diluting effect, there was a clear immobilization of trace metals by the organic matter as reflected by the lower exchangeable concentrations in the compost treatment. It resulted in relative diminution of shoot concentration in $\mathrm{Cd}(-35 \%), \mathrm{Ni}(-40 \%)$, and $\mathrm{Zn}(-15 \%)$ compared to the control at MAS site. Similar effects of organic amendments were reported for other $\mathrm{Cd}$ or $\mathrm{Ni}$ hyperaccumulators (Álvarez-López et al. 2016; Wei et al. 2010). Probably, due to higher bioavailability of trace metals and to the naturally high content in coal and organic matter at GR (18\%), such effect was not observed on that site. The slightly positive effect of compost on individual biomass production for the two NMET populations did not balance this negative impact. This weak biomass effect may be related to the high soil fertility in itself (in the case of GR) and to an inappropriate timing of compost addition that did not permit sufficient compost

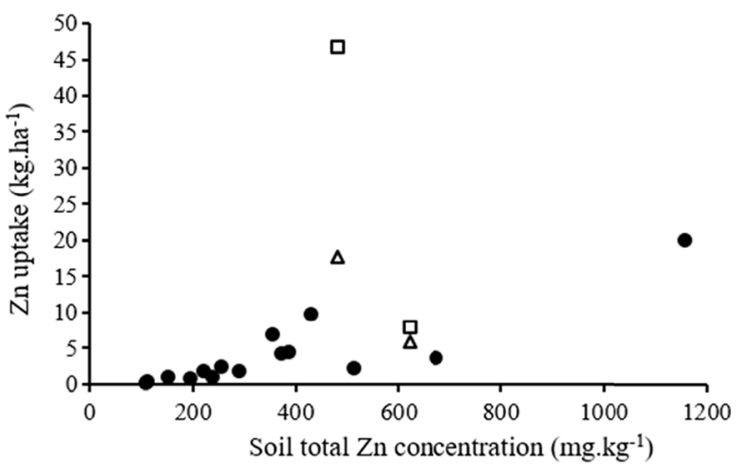

McGrath et al. $2006 n=8$, Maxted et al. $2007 n=6$ ), and from the present study at MAS and GR sites with non-metallicolous populations (open squares) and calamine "Ganges" population (open triangles)

maturation. GAN plants yielded however lower total biomass production on compost at GR and hence lower global metal uptake. This negative effect of compost on GAN survival is not well understood but a possible explanation might be the detrimental effect of a greater soil water retention capacity on plants normally living in a drier climate and on well-drained substrates and therefore inducing a higher mortality caused by pathogens or herbivores. This hypothesis is supported by the fact that there was an average increase of soil moisture by $20 \%$ on the compost treatment compared to the control.

In conclusion, benefits of organic amendments for biomass production were tenuous or even absent in the two sites and did not mitigate the adverse effect of metal immobilization as it was the case in the study of ÁlvarezLópez et al. (2016). On the whole, compost addition is most probably suitable for phytostabilization to stimulate plant growth and mitigate toxic effects of soil trace metals (Vangronsveld et al. 2009). In the case of phytoextraction, further research needs to be done to determine what would be an adequate compost use - timing of application, type of compost, quantity - and on which type of soil it could be favorable.

On the other hand, the fertilization dose used in the second treatment was clearly not adequate to make any reliable conclusions on its potential since it had no general and coherent effect on fertility levels, plant growth, and metal uptake. The fertility level at GR was actually already very high while at MAS, other soil parameters might have limited plant growth. It would be necessary to test the effect of higher doses of fertilizers on plant growth and metal uptake.

\section{Influence of soil on biomass and metal accumulation}

In addition to the population effect, we observed a high variability of biomass production and metal accumulation 
between the two sites and among blocks within them. Globally, the individual metal uptake is mostly influenced by the combination of variables selected for explaining separately individual biomass and shoot concentration, which shows that both plant traits are determinant when trying to improve metal uptake efficiency (Table 4). Soil parameters such as metal content $(\mathrm{Zn}, \mathrm{Cd}$, and $\mathrm{Pb})$ and texture (clay content) explain the biomass and metal accumulation differences within and among sites. Increasing soil $\mathrm{Zn}$ and $\mathrm{Cd}$ exchangeable concentrations are predictably positively impacting plant accumulation but also individual plant biomass in the case of $\mathrm{Zn}$. Previous observations on the positive effect of $\mathrm{Cd}$ on $N$. caerulescens growth have been made (Pongrac et al. 2009; Yanai et al. 2006), while for Zn, it has been mostly shown for MET populations but with no clear effect for NMET (Escarré et al. 2000). Here, we show a positive influence of increasing exchangeable $\mathrm{Zn}$ concentrations on the growth of both MET and NMET populations. However, there might be a threshold concentration above which $\mathrm{Zn}$ no longer stimulates plant growth as suggested by the negative correlation between plant $\mathrm{Zn}$ uptake and exchangeable concentration in the soil at GR (only significant for NMET plants). Such negative effect has already been observed at high and very high $\mathrm{Zn}$ concentrations (1000 and $8000 \mathrm{mg} \mathrm{kg}^{-1}$ ) (Dechamps et al. 2007). Nevertheless, for NMET plants only, the adverse effect of increasing $\mathrm{Zn}$ concentrations at GR might be linked to the jointly increasing $\mathrm{Pb}$ concentrations up to a potentially toxic level (on average $400-500 \mathrm{mg} \mathrm{kg}^{-1}$ total $\mathrm{Pb}$ on both sites, up to $3000 \mathrm{mg} \mathrm{kg}^{-1}$ ). This negative effect did not impact MET plants which are more adapted to such levels of $\mathrm{Pb}$ contamination (Escarré et al. 2000; Reeves et al. 2001). Furthermore, within the range of clay content found on both sites $(8-18 \%)$, individual biomass tends to be higher on soils with more clay, either for chemical or physical reasons. Based on field observations, $N$. caerulescens thrives best on well-drained soils with coarser texture. At these low percentages, clay influence on soil physics is probably weak while its effect on soil exchange complex and its capacity to retain major cations could be more important. This rather supports the hypothesis of a positive impact of clay in terms of chemical fertility. In a pot study, Yanai et al. (2006) showed an opposite effect of texture on Cd uptake by $N$. caerulescens, but within a wider range of clay contents $(2-40 \%)$.

Besides differences of soil texture and of trace metal concentrations, other non-measured physical factors or organic contaminants could explain the remaining fraction of variation and the site effect. Our experimental design does not enable further analysis of the environmental influence on phytoextraction efficiency. This would require a large sample of sites with contrasted conditions to ensure sufficient heterogeneity and enable meaningful inference.

\section{Phytoextraction efficiency on urban soils}

In the perspective of conversion of contaminated soils for urban agriculture, bioavailable contaminant stripping (BCS) (Hamon and McLaughlin 1999) would be an adequate form of remediation. Therefore, in this context, it is relevant to evaluate phytoextraction efficiency by looking at its effect on bioavailable forms of soil trace metals. Relative diminutions in exchangeable forms of about $10 \%$ were recorded in the unplanted subplots, which could be explained by immobilization and insolubilization of the exchangeable fraction and partly lixiviation. When accounting for this effect in the other subplots, the maximum relative diminution that can be attributed to plant uptake was obtained with GAN for $\mathrm{Cd}(-17 \%)$ and with NMET for Zn $(-23 \%)$ at GR, which is very close to what is expected based on plant metal uptake $(-16 \% \mathrm{Cd}$ for GAN and $-27 \% \mathrm{Zn}$ for NMET, based on $20 \mathrm{~cm}$ depth). Based on the results obtained at GR, $\mathrm{Cd}$ and $\mathrm{Zn}$ remediation of urban soils could be achieved within realistic timeframes (less than 5 years) in the case of moderate contamination (i.e., less than 2 and $200 \mu \mathrm{g} \mathrm{g}^{-1}$ of exchangeable $\mathrm{Cd}$ and $\mathrm{Zn}$ in the soil), after choosing appropriate populations, which appears quite promising. However, BCS with $N$. caerulescens seems realistic only in adequate growth conditions to enable sufficient biomass production. Indeed, at MAS, there were no decreases of soil exchangeable forms of $\mathrm{Cd}$ and $\mathrm{Zn}$ but instead significant increases $(10 \%)$. This surprising result could be explained by the very low metal uptake, the solubilization of less mobile forms and the decay of $N$. caerulescens roots. A minimum plant uptake is needed to reach a significant diminution in the soil available fraction. Ideally, in addition to chemical extractions (i.e., with ammonium acetate-EDTA), the diminution of exchangeable forms should be further assessed on the long term - to let the soil solution reach a new equilibrium - by using techniques such as diffusive gradients in thin films (DGT) to mimic the resupply of metals in the soil solution ( $\mathrm{Li}$ et al. 2014). Another way would be to grow vegetable crops accumulating trace metals and use them as a test for metal phytoavailability (Keller and Hammer 2004).

\section{Conclusion}

This field study has demonstrated the interest of using nonmetallicolous populations of $N$. caerulescens for $\mathrm{Zn}$ phytoextraction. Their higher biomass production and $\mathrm{Zn}$ accumulation show the importance of reconsidering the choice of ecotype and/or population when selecting plants for phytoextraction. It appears from our results that phytoextraction with $N$. caerulescens could be an adequate option for both $\mathrm{Cd}$ and $\mathrm{Zn}$ remediation of urban soils 
moderately contaminated once sufficient dry matter production would be reached. Yet, it is unclear which conditions can enable sufficient plant growth for efficient extraction. Our results further suggest to test on various field contaminated soils the relative influence of soil characteristics on $\mathrm{Cd}$ and $\mathrm{Zn}$ uptake: metals of interest $(\mathrm{Cd}, \mathrm{Zn})$, metals with possibly negative effects $(\mathrm{Cu}$ and $\mathrm{Pb})$, and other fertility parameters (texture, $\mathrm{pH}$, major cations). Furthermore, the lack of clear information in field studies on the length and period of growth, the harvest stage, or the planting density, underlines the need to test growth cycles and basic cultural practices to optimize the process.

Acknowledgements This work was financially supported by the Regional Ministry for the Environment, Brussels, BE. A.J. is a research fellow of the Fonds pour la formation à la Recherche dans l'Industrie et dans l'Agriculture (FRIA, Belgium). The authors gratefully acknowledge the regional administration (S. El Fadili, Bernard Lemaire, and R. Rubert from Bruxelles Environnement) and the Contrat de Quartier Durable Bockstael for sites access, and the Centre d'Ecologie Urbaine for project coordination and help in the field.

\section{References}

Alloway BJ (ed) (2012) Heavy metals in soils: trace metals and metalloids in soils and their bioavailability. Environmental Pollution Springer Netherlands. doi:10.1007/978-94-007-4470-7

Álvarez-López V, Prieto-Fernández Á, Cabello-Conejo MI, Kidd PS (2016) Organic amendments for improving biomass production and metal yield of Ni-hyperaccumulating plants. Sci Total Environ 548-549:370-379. doi:10.1016/j.scitotenv.2015.12.147

Beesley L, Moreno-Jiménez E, Gomez-Eyles JL (2010) Effects of biochar and greenwaste compost amendments on mobility, bioavailability and toxicity of inorganic and organic contaminants in a multi-element polluted soil. Environ Pollut 158:2282-2287. doi:10.1016/j.envpol.2010.02.003

Brussels Government (2009) Arrêté du Gouvernement de la Région de Bruxelles-Capitale déterminant les normes d'intervention et les normes d'assainissement, 17 décembre 2009. http://www. environnement.brussels/sites/default/files/user files/arrete_171209_normes1.pdf. Accessed 16 Dec 2016

Bulluck LR, Brosius M, Evanylo GK, Ristaino JB (2002) Organic and synthetic fertility amendments influence soil microbial, physical and chemical properties on organic and conventional farms. Appl Soil Ecol 19:147-160. doi:10.1016/S0929-1393(01)00187-1

Cottenie A, Camerlynck R, Verloo M, Dhaese A (1979) Fractionation and determination of trace elements in plants, soils and sediments. Pure Appl Chem 52:43-53

Dechamps C, Elvinger N, Meerts P, Lefèbvre C, Escarré J, Colling G, Noret N (2011) Life history traits of the pseudometallophyte Thlaspi caerulescens in natural populations from northern Europe. Plant Biol 13:125-135. doi:10.1111/j.1438-8677.2010.00387.x

Dechamps C, Lefebvre C, Noret N, Meerts P (2007) Reaction norms of life history traits in response to zinc in Thlaspi caerulescens from metalliferous and nonmetal liferous sites. New Phytol 173:191-198. doi:10.1111/j.1469-8137.2006.01884.x

Dechamps C, Roosens NH, Hotte C, Meerts P (2005) Growth and mineral element composition in two ecotypes of Thlaspi caerulescens on $\mathrm{Cd}$ contaminated soil. Plant Soil 273:327-335. doi:10.1007/s11104-0050099-0
Development Core Team R (2015) R: a language and environment for statistical computing. R Foundation for Statistical Computing, Vienna

Dubois S (2005) Etude d'un réseau de populations métallicoles et nonmétallicoles de Thlaspi caerulescens (Brassicaceae). Structure génétique, démographie et pressions de sélection. $\mathrm{PhD}$ thesis, Université Montpellier II - Sciences et Techniques du Languedoc, Montpellier, France

Escarré J, Lefèbvre C, Gruber W, Leblanc M, Lepart J, Rivière Y, Delay B (2000) Zinc and cadmium hyperaccumulation by Thlaspi caerulescens from metalliferous and nonmetalliferous sites in the Mediterranean area : implications for phytoremediation. New Phytol. 145:429-437

Finster ME, Gray KA, Binns HJ (2004) Lead levels of edibles grown in contaminated residential soils: a field survey. Sci Total Environ 320: 245-257. doi:10.1016/j.scitotenv.2003.08.009

Geosan (2013) Reconnaissance de l'état du sol, études détaillées et études de risque conjointes, GEOSAN SA, Ref. GERB12844 and GRES12.13189

Gonneau C, Noret N, Godé C, Frérot H, Sirguey C, Sterckeman T, Pauwels M (2016) Demographic history of the trace metal hyperaccumulator Noccaea caerulescens (J. Presl and C. Presl) F. K. Mey. in Western Europe. Mol Ecol. doi:10.1111/mec.13942

Grömping U (2006) Relative importance for linear regression in R : the package relaimpo. J Stat Softw 17:1-27. doi:10.18637/jss.v017.i01

Hammer D, Keller C (2003) Phytoextraction of Cd and Zn with Thlaspi caerulescens in field trials. Soil Use Manag 19:144-149. doi:10.1111/j.1475-2743.2003.tb00295.x

Hamon RE, McLaughlin MJ (1999) Use of the hyperaccumulator Thlaspi caerulescens for bioavailable contaminant stripping In: Wenzel, WW Adriano, DC Alloway, BJ Doner, H Keller, C Lepp, NW (Eds.), Extended Abstracts of the Fifth International Conference on the Biogeochemistry of Trace Elements (ICOBTE). pp. 908-909

Hough RL, Breward N, Young SD, Crout NMJ, Tye AM, Moir AM, Thornton I (2004) Assessing potential risk of heavy metal exposure from consumption of home-produced vegetables by urban populations. Environ Health Perspect 112:215-221

Imperato M, Adamo P, Naimo D, Arienzo M, Stanzione D, Violante P (2003) Spatial distribution of heavy metals in urban soils of Naples city (Italy). Environ Pollut 124:247-256. doi:10.1016/S0269-7491 (02)00478-5

ISO (2007) Norm 23470:2007 Soil quality - Determination of effective cation exchange capacity (CEC) and exchangeable cations using a hexamminecobalt trichloride solution

Jiménez-Ambriz G, Petit C, Bourrié I, Dubois S, Olivieri I, Ronce O (2007) Life history variation in the heavy metal tolerant plant Thlaspi caerulescens growing in a network of contaminated and noncontaminated sites in southern France: role of gene flow, selection and phenotypic plasticity. New Phytol. 173:199-215. doi:10.1111/j.1469-8137.2006.01923.x

Kachenko AG, Singh B (2006) Heavy metals contamination in vegetables grown in urban and metal smelter contaminated sites in Australia. Water Air Soil Pollut 169:101-123

Keller C, Hammer D (2004) Metal availability and soil toxicity after repeated croppings of Thlaspi caerulescens in metal contaminated soils. Environ Pollut 131:243-254. doi:10.1016/j.envpol.2004.02.030

Koopmans GF, Römkens PFAM, Fokkema MJ, Song J, Luo YM, Japenga J, Zhao FJ (2008) Feasibility of phytoextraction to remediate cadmium and zinc contaminated soils. Environ Pollut 156:905914. doi:10.1016/j.envpol.2008.05.029

Krämer U (2010) Metal hyperaccumulation in plants. Annu Rev Plant Biol 61:517-534. doi:10.1146/annurev-arplant-042809-112156

Kruskal W (1987) Relative importance by averaging over orderings. Am Stat 41:6-10 
Li J-T, Baker AJM, Ye Z-H, Wang H-B, Shu W-S (2012) Phytoextraction of Cd-contaminated soils: current status and future challenges. Crit Rev Environ Sci Technol 42:21132152. doi: $10.1080 / 10643389.2011 .574105$

Li X, Poon C, Liu PS (2001) Heavy metal contamination of urban soils and street dusts in Hong Kong. Appl Geochemistry 16:1361-1368. doi:10.1016/S0883-2927(01)00045-2

Li Z, Wu L, Hu P, Luo Y, Zhang H, Christie P (2014) Repeated phytoextraction of four metal-contaminated soils using the cadmium/zinc hyperaccumulator Sedum plumbizincicola. Environ Pollut 189:176-183. doi:10.1016/j.envpol.2014.02.034

Lombi E, Zhao FJ, McGrath SP, Young SD, Sacchi GA (2001) Physiological evidence for a high-affinity cadmium transporter highly expressed in a Thlaspi caerulescens ecotype. New Phytol. 149:53-60. doi:10.1046/j.1469-8137.2001.00003.x

Maxted AP, Black CR, West HM, Crout NMJ, McGrath SP, Young SD (2007) Phytoextraction of cadmium and zinc from arable soils amended with sewage sludge using Thlaspi caerulescens: development of a predictive model. Environ Pollut 150:363-372. doi:10.1016/j.envpol.2007.01.021

McGrath SP, Lombi E, Gray CW, Caille N, Dunham SJ, Zhao FJ (2006) Field evaluation of $\mathrm{Cd}$ and $\mathrm{Zn}$ phytoextraction potential by the hyperaccumulators Thlaspi caerulescens and Arabidopsis halleri. Environ Pollut 141:115-125. doi:10.1016/j.envpol.2005.08.022

Meerts P, van Isacker N (1997) Heavy metal tolerance and accumulation in metallicolous and nonmetalicolous populations of Thlaspi caerulescens from continental Europe. Plant Ecol 133:221-231

Meuser H (2010) Contaminated Urban Soils, Environmental Pollution. Springer Netherlands. doi:10.1007/978-90-481-9328-8

Molitor M, Dechamps C, Gruber W, Meerts P (2005) Thlaspi caerulescens on nonmetalliferous soil in Luxembourg : ecological niche and genetic variation in mineral element composition. New Phytol 165:503-512. doi:10.1111/j.1469-8137.2004.01240.x

Monsant AC, Tang C, Baker AJM (2008) The effect of nitrogen form on rhizosphere soil $\mathrm{pH}$ and zinc phytoextraction by Thlaspi caerulescens. Chemosphere 73:635-642. doi:10.1016/j. chemosphere.2008.07.034

Noret N, Meerts P, Tolrà R, Poschenrieder C, Barceló J, Escarré J (2005) Palatability of Thlaspi caerulescens for snails: influence of zinc and glucosinolates. New Phytol 165:763-772. doi:10.1111/j.14698137.2004.01286.x

Noret N, Meerts P, Vanhaelen M, Dos Santos A, Escarré J (2007) Do metal-rich plants deter herbivores? A field test of the defence hypothesis. Oecologia 152:92-100. doi:10.1007/s00442-006-0635-5

Pansu M, Gautheyrou J (2006) Handbook of soil analysis - mineralogical , organic and inorganic methods. Springer-Verlag, Berlin Heidelberg

Pongrac P, Zhao FJ, Razinger J, Zrimec A, Regvar M (2009) Physiological responses to $\mathrm{Cd}$ and $\mathrm{Zn}$ in two $\mathrm{Cd} / \mathrm{Zn}$ hyperaccumulating Thlaspi species. Environ Exp Bot 66:479-486. doi:10.1016/j.envexpbot.2009.03.010

Reeves RD, Schwartz C, Morel JL, Edmondson J (2001) Distribution and metal-accumulating behavior of Thlaspi caerulescens and associated Metallophytes in France. Int. J. Phytoremediation 3:145-172. doi:10.1080/15226510108500054

Robinson BH, Leblanc M, Petit D, Brooks RR, Kirkman JH, Gregg PEH (1998) The potential of Thlaspi caerulescens for phytoremediation of contaminated soils. Plant Soil 203:47-56. doi:10.1023 /A:1004328816645

Säumel I, Kotsyuk I, Hölscher M, Lenkereit C, Weber F, Kowarik I (2012) How healthy is urban horticulture in high traffic areas? Trace metal concentrations in vegetable crops from plantings within inner city neighbourhoods in berlin. Germany Environ Pollut 165: 124-132. doi:10.1016/j.envpol.2012.02.019

Schwartz C, Echevarria G, Morel JL (2003) Phytoextraction of cadmium with Thlaspi caerulescens. Plant Soil 249:27-35. doi:10.1023 /A:1022584220411

Schwartz C, Sirguey C, Peronny S, Reeves RD, Bourgaud F, Morel JL (2006) Testing of outstanding individuals of Thlaspi caerulescens for cadmium phytoextraction. Int. J. Phytoremediation 8:339-357. doi:10.1080/15226510600992964

Simmons RW, Chaney RL, Angle JS, Kruatrachue M, Klinphoklap S, Reeves RD, Bellamy P (2015) Towards practical cadmium phytoextraction with Noccaea caerulescens. Int. J. Phytoremediation 17:191-199. doi:10.1080/15226514.2013.876961

Sirguey C, Schwartz C, Morel J-L (2006) Response of Thlaspi caerulescens to nitrogen, phosphorus and sulfur fertilisation. Int. J. Phytoremediation 8:149-161. doi:10.1080/15226510600678498

Tlustoš P, Břendová K, Száková J, Najmanová J, Koubová K (2016) The long-term variation of $\mathrm{Cd}$ and $\mathrm{Zn}$ hyperaccumulation by Noccaea spp and Arabidopsis halleri plants in both pot and field conditions. Int $\mathbf{J}$ Phytoremediation 18:110-115. doi:10.1080/15226514.2014.981243

van der Ent A, Baker AJM, Reeves RD, Pollard AJ, Schat H (2013) Hyperaccumulators of metal and metalloid trace elements: facts and fiction. Plant Soil 362:319-334. doi:10.1007/s11104-012-1287-3

Vangronsveld J, Herzig R, Weyens N, Boulet J, Adriaensen K, Ruttens A, Thewys T, Vassilev A, Meers E, Nehnevajova E, van der Lelie D, Mench M (2009) Phytoremediation of contaminated soils and groundwater: lessons from the field. Environ Sci Pollut Res 16: 765-794. doi:10.1007/s11356-009-0213-6

Wang AS, Angle JS, Chaney RL, Delorme TA, Reeves RD (2006) Soil $\mathrm{pH}$ effects on uptake of $\mathrm{Cd}$ and $\mathrm{Zn}$ by Thlaspi caerulescens. Plant Soil 281:325-337. doi:10.1007/s11104-005-4642-9

Wang X, Sato T, Xing B, Tao S (2005) Health risks of heavy metals to the general public in Tianjin, China via consumption of vegetables and fish. Sci Total Environ 350:28-37. doi:10.1016/j. scitotenv.2004.09.044

Wei S, Li Y, Zhou Q, Srivastava M, Chiu S, Zhan J, Wu Z, Sun T (2010) Effect of fertilizer amendments on phytoremediation of $\mathrm{Cd}$ contaminated soil by a newly discovered hyperaccumulator Solanum nigrum L. J Hazard Mater 176:269-273. doi:10.1016/j. jhazmat.2009.11.023

Wong CSC, Li X, Thornton I (2006) Urban environmental geochemistry of trace metals. Environ Pollut 142:1-16. doi:10.1016/j. envpol.2005.09.004

Yanai J, Zhao FJ, McGrath SP, Kosaki T (2006) Effect of soil characteristics on Cd uptake by the hyperaccumulator Thlaspi caerulescens. Environ Pollut 139:167-175. doi:10.1016/j.envpol.2005.03.013

Zhao FJ, Lombi E, McGrath SP (2003) Assessing the potential for zinc and cadmium phytoremediation with the hyperaccumulator Thlaspi caerulescens. Plant Soil 249:37-43. doi:10.1023/A:1022530217289 